\title{
A Semi-automated Instrument for Cellular Oxidative Potential Evaluation (SCOPE) of Water-soluble Extracts of Ambient Particulate Matter
}

\section{Sudheer Salana, Yixiang Wang, Joseph V. Puthussery, Vishal Verma}

Department of Civil and Environmental Engineering, University of Illinois at Urbana-Champaign, Urbana, 61801, USA

Correspondence to: Vishal Verma (vverma@illinois.edu)

Abstract. Several automated instruments exist to measure the acellular oxidative potential (OP) of ambient particulate matter (PM). However, cellular OP of the ambient PM is still measured manually, which severely limits the comparison between two

10 types of assays. Cellular assays could provide a more comprehensive assessment of the PM-induced oxidative stress, as they incorporate more biological processes involved in the PM-catalyzed reactive oxygen species (ROS) generation. Considering this need, we developed a first of its kind semi-automated instrument for measuring the cellular OP based on a macrophage ROS assay using rat alveolar macrophages. The instrument named SCOPE - Semi-automated instrument for Cellular Oxidative Potential Evaluation, uses dichlorofluorescein diacetate (DCFH-DA) as a probe to detect the OP of PM samples extracted in

15 water. SCOPE is capable of analyzing a batch of six samples (including one negative and one positive control) in five hours and is equipped to operate continuously for 24-hours with minimal manual intervention after every batch of analysis, i.e., after every five hours. SCOPE has a high analytical precision as assessed from both positive controls and ambient PM samples $(\mathrm{CoV}<17 \%)$. The results obtained from the instrument were in good agreement with manual measurements using tert-Butyl hydroperoxide $(\mathrm{t}-\mathrm{BOOH})$ as the positive control (slope $=0.83$ for automated vs. manual, $\mathrm{R}^{2}=0.99$ ) and ambient samples

20 (slope $=0.83, \mathrm{R}^{2}=0.71$ ). We further demonstrated the ability of SCOPE to analyze a large number of both ambient and laboratory samples, and developed a dataset on the intrinsic cellular OP of several compounds, such as metals, quinones, PAHs and inorganic salts, commonly known to be present in ambient PM. This dataset is potentially useful in future studies to apportion the contribution of key chemical species in the overall cellular OP of ambient PM.

\section{Introduction}

25 Epidemiological models have traditionally relied on mass of the particulate matter (PM) as a metric to associate the health effects such as wheeze (Doiron et al., 2017; Karakatsani et al., 2012), asthma (Holm et al., 2018; Wu et al., 2019; Zmirou et al., 2002), myocardial infarction and coronary heart disease (Yang et al., 2019), ischemic heart disease and dysrhythmias (Pope et al., 2004) and heart rate variability (Breitner et al., 2019; Pieters et al., 2012; Riojas-Rodriguez et al., 2006) with the inhalation of ambient and indoor PM. However, mass is not a wholesome metric as it does not capture the diverse range of particle physicochemical characteristics. Apparently, the assumption that an increase in PM mass alone leads to a proportionate 
increase in the mortality would yield erroneous estimates if we do not account for the complexity of PM chemical composition and the resulting intrinsic toxicities. There are also mounting evidence that toxic effects of different chemical components are not simply additive, but there exists both synergistic and antagonistic interactions (Wang et al., 2020; Yu et al., 2018). Therefore, we need a metric of the PM along with mass that can provide some relevant information to assess its toxicity. Oxidative stress has emerged as one of such metrics, which has been identified as a crucial step in the progression of many human diseases.

Oxidative stress is caused by an imbalance between reactive oxygen species (ROS) generation and their subsequent scavenging by lung antioxidants (Kryston et al., 2011; Li et al., 2008; Møller et al., 2010; Rao et al., 2018; Reuter et al., 2010). Thus, measuring the ability of PM to induce ROS generation in the respiratory system, also called the oxidative potential (OP), could be considered as one of the markers of its toxicity and accordingly several acellular assays have been developed in the recent past to measure the OP of PM. These include the dithiothreitol (DTT) assay (Charrier and Anastasio 2012; Fang et al., 2015), ascorbic acid (AA) assay (Künzli et al., 2006; Visentin et al., 2016), glutathione assay (Künzli et al., 2006; Mudway et al., 2005), and hydroxyl radical $(\bullet \mathrm{OH})$ measurement (Vidrio et al., 2009; Xiong et al., 2017). Along the similar lines, several cellular assays have also been developed, which involve molecular probes that can detect ROS through their transformation from non-fluorescent to fluorescent forms (Dikalov and Harrison 2014; Kuznetsov et al., 2011; Landreman et al., 2008; Wan et al., 1993). However, measurement of OP of PM using both cellular and acellular assays is often a labor-intensive and timeconsuming process and therefore manually analyzing a large number of ambient samples for spatiotemporal resolution of OP is a cumbersome process.

In the last few years, a number of automated instruments have been developed based on acellular assays which could provide 50 rapid and high-throughput analyses of the PM chemical OP (Berg et al., 2020; Fang et al., 2015; Gao et al., 2017; Venkatachari and Hopke 2008). There have also been a number of online instruments which can be deployed in the field making it possible to collect real-time OP or ROS data (Brown et al., 2019; Huang et al., 2016; Puthussery et al., 2018; Sameenoi et al., 2012; Wragg et al., 2016; Zhou et al., 2018). Although, acellular assays have many advantages over cellular assays such as ease of application, low maintenance and no risk of microbial contamination, they are unable to capture the complex biochemical reactions occurring in a biological system as a response to PM exposure. This could be one of the reasons for their inconsistent correlations with various biological responses such as DNA damage and expression of inflammatory cytokines in previous studies (Crobeddu et al., 2017; Janssen et al., 2015; Øvrevik 2019; Steenhof et al., 2011). Cellular assays have an edge in this regard as these assays directly expose biological cells to chemical constituents of the particles, thus capturing some, if not all, of the biochemical processes related to the oxidative burst. However, to the best of our knowledge, no automated instrument

60 has ever been developed to provide a rapid high-throughput analysis of the cellular OP induced by the ambient PM. In comparison to chemical assays, cellular assays are even more time and labor-intensive. Due to this strenuous nature of the cellular protocols, there have been very limited comparison between the chemical and cellular OP measurements. There is a 
need for the development of an automated instrument for the cell-based measurement of OP, which could not only analyze a large number of samples in shorter period with minimal manual intervention, but could also open up the possibilities for developing a field-deployable real-time instrument measuring cellular OP. Having such an automated instrument would be able to provide a direct comparison of cellular and acellular assays, thus screening the important chemical OP endpoints. Such advances will also help in integrating the OP data in toxicological and/or epidemiological studies by yielding a relatively large dataset on these measurements.

In this paper, we describe the development of a semi-automated instrument for cellular oxidative potential evaluation (SCOPE).

70 SCOPE is the first of its kind instrument to measure the cellular OP induced by the water-soluble ambient PM extracts in murine alveolar cell line NR8383, using an automated protocol. The instrument is capable of analyzing a batch of six samples (including one negative and one positive control) in five hours. SCOPE is equipped to operate continuously for 24-hours with minimal manual intervention after every batch of analysis, i.e., after every five hours. We also calculated the detection limit of this instrument and evaluated its performance by measuring precision and accuracy using both positive controls and ambient samples. Finally, we demonstrated the ability of SCOPE to analyze a large number of both ambient and laboratory samples, and developed a dataset on the intrinsic cellular OP of several compounds, such as metals, quinones, polycyclic aromatic hydrocarbons (PAHs) and inorganic salts, commonly known to be present in the ambient PM.

\section{Materials and Methods}

\subsection{Chemicals}

80 Copper (II) sulphate pentahydrate [Cu (II)] ( $\geq 98 \%$ ), Luperox ${ }^{\circledR}$ TBH70X, tert-Butyl hydro peroxide (t-BOOH) solution (70 wt. \% in water), iron (II) sulphate heptahydrate [Fe(II)] ( $\geq 99 \%$ ), manganese (II) chloride tetrahydrate [Mn(II)] ( $\geq 98 \%$ ), zinc (II) nitrate hexahydrate [Zn(II)] ( $\geq 98 \%$ ), iron (III) chloride hexahydrate [Fe(III)] ( $\geq 97 \%$ ), lead (II) acetate trihydrate [Pb(II)] ( $\geq 98 \%$ ), aluminum (III) nitrate nonahydrate [Al(III)] ( $\geq 98 \%$ ), chromium(III) nitrate nonahydrate [Cr(III)] ( $\geq 97 \%$ ), cadmium (II) nitrate tetrahydrate $[\mathrm{Cd}(\mathrm{II})](\geq 98 \%)$, vanadium (III) chloride $\mathrm{V}$ (III) $(97 \%)$, nickel (II) chloride hexahydrate [Ni(II)]

85 (99.9\%), 9,10-phenanthraquinone (PQN) (99\%), 1,2-naphthaquinone (1,2-NQN) (97\%), 1,4-naphthaquinone (1,4-NQN) (97\%), 5-hydroxyl-1,4-naphthaquinone (5-H-1,4-NQN) (97\%), pyrene (Pyr) (98\%), naphthalene (Naph) (99\%), anthracene (Anth) (97\%), phenanthrene (Phen) (98\%), benzo[a]pyrene (B[a]P) ( $\geq 96 \%)$, fluorene (Flu) (98\%), benz[a]anthracene (B[a]A) (99\%), sodium chloride $(\mathrm{NaCl})(\geq 99 \%)$, ammonium nitrate $\left(\mathrm{NH}_{4} \mathrm{NO}_{3}\right)(\geq 99 \%), 2^{\prime}, 7^{\prime}$-dichlorofluorescin diacetate (DCFH-DA), zymosan A from saccharomyces cerevisiae, Ham's F-12K growth media, and fetal bovine serum (FBS) were purchased from

90 Sigma Aldrich Co. (St.Louis, MO). Ammonium chloride $\left(\mathrm{NH}_{4} \mathrm{Cl}\right)$ and calcium chloride $\left(\mathrm{CaCl}_{2}\right)$ were purchased from VWR Life Sciences. Ammonium sulphate $\left(\mathrm{NH}_{4} \mathrm{SO}_{4}\right)$ and potassium chloride $(\mathrm{KCl})$ were purchased from Fisher Scientific. Salt 
glucose media (SGM) at two different concentrations (1X and 10X), which was prepared according to the composition discussed in Klein et al., (2002), was provided by the Cell Media Facility at UIUC.

\subsection{Stock Solution Preparation}

95 The stock solutions of quinones (PQN, 1,2-NQN, 1,4-NQN) were prepared in DMSO and stored in a freezer at $-20^{\circ} \mathrm{C}$ for one week. The stock solution of 5-H-1,4-NQN was prepared on the same day of the experiment as it was found to be relatively unstable (e.g., change in color over a period of more than 24 hours) compared to other quinones. The stock solutions of PAHs (anthracene, pyrene, naphthalene, fluorene, phenanthrene, $\mathrm{Ba}[\mathrm{A}] \mathrm{P}$, and $\mathrm{Ba}[\mathrm{A}] \mathrm{A}$ ) were prepared in methanol and stored in a freezer at $-20{ }^{\circ} \mathrm{C}$ for one week. On the day of the experiment, the stock solutions of both quinones and PAHs were diluted using Milli-Q deionized water $(\mathrm{DI}$, resistivity $=18.2 \mathrm{M} \Omega / \mathrm{cm}$ ) to appropriate concentrations. All the metals, inorganic salt and $\mathrm{t}-\mathrm{BOOH}$ solutions were freshly prepared using DI on the day of the experiments and immediately used.

\subsection{Cells}

Alveolar macrophages form the front-line of defense in pulmonary region of respiratory system against attack by the foreign particles. These cells play a major role in preliminary responses such as phagocytosis, secreting pro-inflammatory cytokines and killing pathogens. We used a murine alveolar cell line, NR8383, which resembles greatly to the primary macrophages in terms of their expression of cytokines and other biological responses, thus serving as a good model for the PM toxicity studies (Lane et al., 1998; Lin et al., 2000). The cells were maintained on glass culture plates in Ham's F12-K medium containing 5\% FBS and incubated at $37{ }^{\circ} \mathrm{C}$ with $5 \% \mathrm{CO}_{2}$ concentration. The cells were cultured by transferring floating cells from culture plates to fresh plates every four weeks. The cells generally divide and double in concentration within 48 hours (Helmke et al.,

110 1987), after which the floating cells are removed for further growth of the attached cells by adding fresh media. Since Ham's F-12K media could itself contribute to the fluorescence, it was replaced by 1XSGM after counting the initial cell density and subsequent centrifugation, such that final concentration of the cells in SGM is 2000 cells $/ \mu \mathrm{L}$.

\subsection{Probe Preparation}

A $45 \mathrm{mM}$ stock solution of DCFH-DA was prepared and aliquoted into different vials ( $30 \mu \mathrm{L}$ per vial). These vials were stored

115 in a freezer $\left(\right.$ at $-20^{\circ} \mathrm{C}$ ) and used within a month. To prepare the final probe solution, a portion of the content of one vial (i.e., $25 \mu \mathrm{L}$ of $45 \mathrm{mM}$ DCFH-DA) was diluted 100 times just before the experiment, using 10X SGM.

\subsection{System Setup}

We adapted the method of macrophage ROS assay from Landreman et al., (2008) which is the most widely used protocol for measuring the cellular OP of ambient PM. In this assay, DCFH-DA is used as an ROS probe. The reaction mechanism of DCFH-DA with ROS is well established (Rosenkranz et al., 1992; Wan et al., 1993). Briefly, DCFH-DA is a cell permeable compound which undergoes deacetylation by intracellular esterase to form DCFH. DCFH is oxidized by a variety of ROS to 
form a fluorescent product called DCF. The intensity of fluorescence provides a direct measure of the ROS generation. In our protocol, all the components of the assay, i.e., PM extract (or negative control/positive control; $138 \mu \mathrm{L}$ ), molecular probe (DCFH-DA; $39 \mu \mathrm{L}$ ), and cells suspension $(177 \mu \mathrm{L}$ at a final concentration of 1000 cells per $\mu \mathrm{L}$ in the reaction vial (RV)) are added together and incubated for 2 hours. Next, a small aliquot is withdrawn and transferred to a spectrofluorometer after dilution to measure the fluorescence.

The schematic diagram of SCOPE based on this protocol is shown in Fig. 1. The instrument consists of four major units: cells reservoir and samples holder, fluid transfer unit, incubation-cum-reaction unit, and measurement unit. The cells reservoir and sample holder consist of a set of seven vials (15 mL each) - one containing NR8383 cells suspended in 1XSGM, one amber vial containing DCFH-DA solution, five vials containing samples (i.e., four PM samples and one positive control). All the vials of this unit were placed in an Eppendorf Thermo-Mixer (Eppendorf North America, Hauppauge, NY, USA), which is maintained at $37^{\circ} \mathrm{C}$ while continuously shaking at a frequency of $600 \mathrm{RPM}$. The fluid transfer unit consists of three Kloehn programmable syringe pumps (IMI precision, Littleton, CO, USA) (Pump \#1, 2, and 3; see Fig. 1) and a 14-port multi-position valve (VICI® Valco Instrument Co. Inc., Houston, TX, USA) connected to Pump \#2. The incubation-cum-reaction unit consists of $17 \mathrm{RVs}$ [amber vials, $2 \mathrm{~mL}$ each; 1 for negative control (DI) in triplicate, 1 for positive control (t-BOOH) in duplicates and 4 for PM samples in triplicates] held in another Eppendorf Thermo-Mixer which is maintained at $37{ }^{\circ} \mathrm{C}$ and continuously shaking at a frequency of 800 RPM to keep the contents of all the vials well-mixed and suspended. 14 of these RVs are connected to Pump \# 2 through the multi-position valve. Each RV connected to the multi-position valve is accessed by changing the valve position [using a valve actuator $\left(\mathrm{VICI}{ }^{\circledR}\right)$ ] to its respective number. Since multi-position valve has only

14 ports, rest 3 RVs are directly connected to Pump \#3. Both of these pumps (i.e., \#2 and 3) transfer the content from various reservoirs (e.g., cells, DI and DCFH-DA) to RVs, and also transfer a small aliquot from these RVs (50 $\mu$ L from each RV) to the measurement vial (MV) after 2 hours of reaction. Finally, the measurement unit consists of a Fluoromax-4 spectrofluorometer (Horiba Scientific, Edison, NJ, USA) equipped with a Flowcell (Horiba Scientific, HPLC Flowcell- $25 \mu \mathrm{L}$ volume) to measure the fluorescence generated from the reaction of DCFH and cellular ROS. Pump \#1, which is connected to the MV and the spectrofluorometer, first dilutes the aliquot withdrawn from the RV and then transfers this diluted mixture from MV to the spectrofluorometer for fluorescence measurement.

\subsection{OP Measurement Protocol}

The protocol for measuring cellular OP involves two stages -the first stage consists of manual preparation of the cells, DCFHDA probe, and PM extracts, while the second stage involves incubating the cells with PM and DCFH and measuring the fluorescence in an automated manner. After preparing the cells, DCFH-DA and different PM extracts (i.e., completion of first stage), all the vials are manually transferred to the cell reservoir and sample holder. The second stage (automation stage) further consists of two phases - reaction phase and measurement phase. The complete algorithm of 2nd stage is shown in Fig. 2. In the reaction phase, various reactants (i.e., cells, DCFH-DA and PM extract or positive control of DI) are transferred from their respective reservoirs to the RVs using pump \# 2 and 3. This is done in a sequence of steps: in the first step, $138 \mu \mathrm{L}$ of DI is 
withdrawn using Pump \#2 and transferred via the multi-position valve to three RVs marked for negative control (i.e., triplicate analysis of the negative control). In the second step, $177 \mu \mathrm{L}$ cell solution is withdrawn from the cell reservoir using Pump \# 2 and transferred sequentially to all $14 \mathrm{RVs}$ via multi-position valve. Simultaneous to this step, $177 \mu \mathrm{L}$ cell solution is withdrawn from the cell reservoir using Pump \# 3 and transferred to three RVs connected to that pump. In the third step, $39 \mu \mathrm{L}$ DCFHDA is transferred using pump \#2 and pump \#3 to the respective RVs connected to them (i.e., $14 \mathrm{RVs}$ connected to pump \#2 through the multi-position valve and $3 \mathrm{RVs}$ directly connected to pump \#3) following the same sequential order as for addition of the cell solution. Finally, $138 \mu \mathrm{L}$ of positive control (t-BOOH) and PM extracts are transferred to the respective RVs using Pump \#2 and \# 3, i.e., t-BOOH and 3 PM extracts are transferred using Pump \# 2 via multi-position valve, while one PM extract using Pump \# 3 directly connected to 3 RVs. After all the RVs are loaded with the reactants, SCOPE performs a single round of self-cleaning, in which all the valves and tubing of the instrument are rinsed with DI using the fluid handling unit

165 (i.e., all three Kloehn pumps).

After 2 hours of cells' exposure to PM, the measurement phase starts in which the fluorescence of DCF formed in each RV is measured in a sequential manner. Each measurement involves three steps- 1) withdrawing an aliquot of $50 \mu \mathrm{L}$ from the RV (using Pump \#2 for 14 RVs connected to it, and Pump \#3 for the remaining 3 RVs) and transferring it to the MV; 2) diluting the aliquot 100 times by adding DI using Pump \#1 to the MV, and finally 3) pushing the diluted aliquot through Flowcell of

170 the spectrofluorometer using the same syringe Pump \#1. The withdrawal of the aliquot from different RVs follows the same order as for their preparation, such that the cells in each vial undergo exposure to the PM extract or DI or t-BOOH for exactly 2 hours. The spectrofluorometer is preset at an excitation/emission wavelength of $488 \mathrm{~nm} / 530 \mathrm{~nm}$. Between successive fluorescence measurements of different RVs, the Flowcell, MV and the tubing connected to the multi-position valve are thoroughly rinsed with at least $10 \mathrm{~mL}$ of DI. After all RVs are measured for fluorescence, the instrument performs a final round of thorough self-cleaning, wherein each valve and tubing are cleaned (three times) with $70 \%$ ethanol followed by DI. All the RVs and MV after this cleaning step are disposed and replaced manually with clean empty vials. SCOPE takes about five hours for complete analysis of one batch of six samples (i.e., 4 PM extracts, one negative and one positive control). For the next batch of analysis, cells, DCFH-DA and samples are manually replaced with freshly prepared vials. In our experiments for this manuscript, one batch was run per day, although it is possible to run up to three batches (a total of twelve PM samples) per day.

\subsection{Ambient PM Sample Collection and Preparation}

Ambient $\mathrm{PM}_{2.5}$ samples were used in this study for assessing the precision and accuracy of SCOPE. These ambient samples were collected as a part of the Midwest Sampling Campaign and the sampling procedure and collection protocol are described elsewhere (Yu et al., 2019). Briefly, PM $_{2.5}$ samples were collected on quartz filters (Pall Tissuquartz TM, 8”x10") using a

185 high-volume sampler (flow rate of $1.13 \mathrm{~m}^{3} / \mathrm{min} ; \mathrm{PM}_{2.5}$ inlets, Tisch Environmental; Cleves, $\mathrm{OH}$ ) from five different sites in the midwestern USA: a road-side site in Champaign (within the UIUC campus), a rural site in Bondville (IL), and three urban sites in Chicago, IL (university campus of Illinois Institute of Technology), Indianapolis, IN (Indiana University-Purdue 
University campus), and St. Louis, MO [a part of National Core Pollutants (NCore) Network of USEPA]. All the samples used in this study were collected between May 2018 and May 2019. A total of 50 samples from all the five sites (10 from Indianapolis, 9 from Chicago, 10 from St. Louis, 7 from Bondville and 14 from Champaign) were used for conducting the performance evaluation, i.e., assessing precision and accuracy of the instrument. Further details on these samples (i.e., dates of collection, exact mass loadings etc.) are provided in Table S1 of the supplemental information (SI).

\subsection{Filters Extraction}

A single circular section of 1" diameter was punched from the high-volume filter, immersed in DI and sonicated for 60 minutes in an ultrasonic water bath (Cole-Palmer, Vernon-Hills, IL, USA). The volume of DI was determined based on the $\mathrm{PM}_{2.5}$ mass loading on each punched section, such that the final concentration of the extract for exposure in the RV is $30 \mu \mathrm{g} / \mathrm{mL}$. After sonication, the extracts were passed through a $0.45 \mu \mathrm{m}$ pore size polytetrafluoroethylene (PTFE) filter to remove any insoluble particles and/or filter fibers. The water-soluble $\mathrm{PM}_{2.5}$ extracts were then used to measure the OP of the PM.

\section{Results and Discussions}

\subsection{Instrument Calibration}

The results of OP of the samples (i.e., field blank filter, positive control or PM extract) are reported as the percentage increase in fluorescence relative to the negative control (i.e., cells treated with DI), which is consistent with many previous studies (Sun et al., 2011; Thayyullathil et al., 2008; Wan et al., 2012; Wang et al., 2012). Normalizing by the negative control which is analyzed in the same batch of the samples is important, because absolute fluorescence of the cells treated with negative control is not stable and vary in each experiment. Two factors could cause this variability in apparent response of the cells. First, DCFH-DA, being a photo-chemically active compound (Castro-Alférez et al., 2016; Chen et al., 2010), could itself undergo possible decay and slight photo-degradation over time. Second, the exposed cells could be under different developmental stages, which affects their metabolic activity and the subsequent generation of ROS. Both of these factors yield substantial variability [Coefficient of variation $(\mathrm{CoV})=35 \%$, as obtained from the experiments conducted on 20 different days] in absolute fluorescence of the cells treated with DI (see Fig. S1 in the supplementary information). However, normalizing the fluorescence of a sample with that of the negative control minimizes this variability. For example, $\mathrm{CoV}$ for the ratio of the fluorescence caused by the positive controls (zymosan, concentration $=100 \mu \mathrm{g} / \mathrm{mL}$ ) versus respective negative controls was only $16 \%$ (Fig. S1). Therefore, fluorescence of all the samples (i.e., filter blank, field blank, positive control or PM extract) was normalized with that of the negative control, analyzed in the same batch of the samples. This normalized fluorescence of the sample was then blank corrected by subtracting corresponding fluorescence of the blank, which was DI for the positive control and field blank filter extract for the PM extract.

Fig. 3 shows the response curve for various concentrations of t-BOOH $(3.51-87.83 \mathrm{mg} / \mathrm{mL})$, which was used to calibrate the instrument. The calibration equation shown in Fig. 3 was used to convert the blank-corrected OP (\% increase in fluorescence) 
to the equivalent units of $\mathrm{mg} / \mathrm{mL}$ t-BOOH (see Sect $\mathrm{S} 1$ in the supplementary information for calculations). At concentrations higher than $87.83 \mathrm{mg} / \mathrm{mL}$ t-BOOH, the curve becomes non-linear (see Fig. S2 in the supplemental information), but here we show only linear portion of the curve for the convenience of calculating the calibration equation.

\subsection{Limit of Detection (LOD)}

The LOD of SCOPE is defined as three times the standard deviation of multiple blanks. For this study, the LOD was calculated from the field blank filters ( $\mathrm{FB}, \mathrm{N}=10$ ) analyzed in different batches. As discussed earlier, the OP response from these blanks was expressed as percentage increase in fluorescence with respect to corresponding negative control (analyzed in the same batch as FB). The LOD obtained from the average and standard deviation of this data is converted to equivalent units of $\mathrm{t}$ BOOH $(\mathrm{mg} / \mathrm{mL})$ using the calibration equation shown in Fig. 4. The LOD obtained by this method is $1.26 \mathrm{mg} / \mathrm{mL}$ t-BOOH. Note, an ideal expression of LOD should have been in terms of the threshold PM mass required to yield a signal significantly distinguishable from the blanks, however, expressing LOD in those units is complicated given the variability associated with PM, such as different chemical composition of the PM samples collected on different days and the variability in extraction procedures (e.g., volume of water used for PM extraction and the filter area which can be submerged in that volume).

\subsection{Precision}

For determining analytical precision of SCOPE, three different types of samples, i.e., positive controls $(9.75 \mathrm{mM} \mathrm{t}-\mathrm{BOOH}$ and $100 \mu \mathrm{g} / \mathrm{mL}$ Zymosan), $\mathrm{Cu}$ (II) solution $(20 \mu \mathrm{M})$, and water-soluble PM extracts were used. For PM extracts, ten different circular sections (each 1" in diameter) were punched from ten different spots on one of the high-volume filters collected in the Midwest Sampling Campaign (Sect. 2.7) and extracted in DI (Sect. 2.8). The blank corrected \% normalized OP response of the PM extract was further normalized by the PM mass used in the RV for exposure to the cells. Table 1 shows the average, standard deviation and $\mathrm{CoV}$ obtained from the measurements of various samples.

The instrument showed a CoV less than $20 \%$ for most cases suggesting high reproducibility of the results. Among the positive controls, $\mathrm{CoV}$ for zymosan was the highest (39\%), as compared to $14 \%, 14 \%$ and $16 \%$ obtained for Cu (II), PM samples and $\mathrm{t}-\mathrm{BOOH}$, respectively. We suspect that higher $\mathrm{CoV}$ for zymosan is partly due to water-insoluble nature of zymosan (Gao et al., 2012; Venkatachalam et al., 2020), which is often used as a suspended particle in phagocytosis assays (Sung et al., 1983; Thomas et al., 2007; Underhill, 2003). This could lead to deposition of zymosan particles inside tubing of the instrument, leading to an underestimation in the OP measurement. In contrast, t-BOOH is highly water-soluble $[700,000 \mathrm{mg} / \mathrm{L}$ (OECD/SIDS, 1995)] and thus involves no such complications. t-BOOH has previously been shown to induce oxidative stress not only in macrophages (Lopes et al., 2017; Prasad et al., 2007; Roux et al., 2019) but also in a variety of other cells such as hepatocytes (Kučera et al., 2014), sperm cells (Fatemi et al., 2012), and lung fibroblast cells (Lopes et al., 2017). These results suggest that $\mathrm{t}-\mathrm{BOOH}$ could be a more reliable positive control than zymosan for the macrophage ROS assay, particularly for the automated operation of our instrument. 


\subsection{Accuracy}

The accuracy of SCOPE was evaluated by comparing the instrument's response with that obtained from the manual operation using both positive controls and ambient PM samples. We prepared different concentrations of t-BOOH from 0.04 to $9.75 \mathrm{mM}$ $(0.04,0.39,0.97,1.95$ and $9.75 \mathrm{mM}$, in the RVs used for exposure to the macrophages), and analyses were conducted both manually and using the instrument. Fig. 4 shows the comparison of manual and automated measurements of ROS induced by various concentrations of t-BOOH. The slope of the automated versus manual measurements for the positive control was $\sim 0.83$ with a very high coefficient of determination $\left(r^{2}=0.99\right)$. The automated measurements were slightly but consistently lower than the manual measurements. This bias could probably be caused by the error introduced during transfer of cells using the fluid-transfer unit (i.e., some loss of cells in valves or tubing), leading to slight inconsistency of the cell density in RVs. Though, this deposition of the cells is not expected to yield cross contamination of the samples, given a rigorous cleaning procedure (as discussed in Sect. 2.6) employed during operation of the instrument.

One of the major objectives of developing SCOPE was to enable a high through-put analysis of the PM samples. To demonstrate this ability of the instrument, fifty ambient $\mathrm{PM}_{2.5}$ samples collected from various sites in the Midwest US (Sect. 2.7) were analyzed and the results from the automated instrument were compared with manual measurements. The results are expressed in terms of the equivalent units of t-BOOH (mg of t-BOOH per mg of PM), and the comparison is shown in Fig. 5 (see Sect. S1 of the supplementary information for the calculation procedure). Overall, there was very good comparison between the manual and automated measurements, with a slope of 0.83 and a coefficient of determination $\left(r^{2}\right)=0.71$.

\subsection{Intrinsic OP of individual PM chemical species}

To demonstrate the utility of SCOPE, we tested several compounds commonly known to be present in the ambient PM. These include 11 metallic species [Fe (II), $\mathrm{Fe}$ (III), $\mathrm{Cu}(\mathrm{II}), \mathrm{Mn}$ (II), $\mathrm{Zn}$ (II), $\mathrm{Al}$ (III), $\mathrm{Pb}$ (II), $\mathrm{Cr}$ (III), Cd (II), $\mathrm{V}$ (III) and Ni (II)], 4 quinones (PQN, 1,4-NQN, 1,2-NQN and 5-H-1,4-NQN), 7 PAHs (Phenanthrene, Anthracene, Naphthalene, Pyrene, Fluorene, $\mathrm{B}[\mathrm{a}] \mathrm{P}$ and $\mathrm{B}[\mathrm{a}] \mathrm{A})$ and 6 inorganic salts $\left(\mathrm{KCl}, \mathrm{NaCl}, \mathrm{NH}_{4} \mathrm{Cl}, \mathrm{NH}_{4} \mathrm{NO}_{3}, \mathrm{NH}_{4} \mathrm{SO}_{4}\right.$ and $\left.\mathrm{CaCl}_{2}\right)$. The concentrations used for these compounds, i.e., $0.5 \mu \mathrm{M}$ for metals, $0.2 \mu \mathrm{M}$ for quinones and PAHs, $5 \mu \mathrm{M}$ for $\mathrm{KCl}, \mathrm{NH}_{4} \mathrm{Cl}, \mathrm{NH}_{4} \mathrm{NO}_{3}, \mathrm{NH}_{4} \mathrm{SO}_{4}, \mathrm{CaCl}_{2}$ and 1 $\mu \mathrm{M}$ for $\mathrm{NaCl}$, were in their typical ranges present in the ambient $\mathrm{PM}_{2.5}$ and similar to those used in previous studies based on acellular assays (Charrier and Anastasio, 2012; Yu et al., 2018). We are not aware of any study which has systematically

275 explored and compared the DCFH-based OP of individual PAHs vs. various metals or quinones in alveolar macrophages (murine cell line NR8383). Fig. 6 shows the OP of these chemical species. Among metals, Fe (II), Mn (II), and Cu (II) induced the highest response (12.40 -9.95 mg/mL t-BOOH). In contrast, metals such as $\mathrm{Zn}$ (II), $\mathrm{Pb}$ (II), $\mathrm{Al}$ (III), $\mathrm{Cr}$ (III), $\mathrm{Cd}$ (II), V(III) induced low response $(<4.5 \mathrm{mg} / \mathrm{mL}$ t-BOOH). $\mathrm{Ni}$ (II) caused almost negligible oxidative stress (about 20 times lower than that of $\mathrm{Fe}(\mathrm{II}))$ and the response was lower than LOD of the instrument. Interestingly, Fe (III) induced comparatively much lower response ( $\sim 3$ times lower) than Fe (II), which matches with their relative redox activities as measured by the dithiothreitol (DTT) assay, i.e., 3 times lower intrinsic DTT activity of Fe (III) compared to Fe (II) (Charrier and Anastasio, 2012). 
Among the organic compounds, quinones dominated the OP. PQN, 1,2-NQN, 1,4-NQN showed the highest response (7.51$4.92 \mathrm{mg} / \mathrm{mL}$ t-BOOH) and followed $\mathrm{Fe}$ (II), $\mathrm{Mn}$ (II) and $\mathrm{Cu}$ (II) in the decreasing order of response. In contrast, 5-H-1,4-NQN showed a very low response of $2.87 \mathrm{mg} / \mathrm{mL}$ t-BOOH. PQN, 1,2-NQN and 1,4-NQN are among the most abundantly found quinones in ambient air (Charrier and Anastasio, 2012), known to show a high redox cycling capability transitioning to and from their semiquinone forms, as well as the ability to cause DNA damage and induce apoptosis in cells (Klotz et al., 2014; Shang et al., 2014; Shinkai et al., 2012; Yang et al., 2018). Therefore, a high intrinsic OP of these quinones indicates towards their prominent role in other cellular responses such as inflammation and cell death.

PAHs showed very low response $(<4 \mathrm{mg} / \mathrm{mL} \mathrm{t}-\mathrm{BOOH})$, and the differences among their responses were not significant at the concentration tested in our experiments (i.e., $0.2 \mu \mathrm{M})$. Phenanthrene and $\mathrm{B}[\mathrm{a}] \mathrm{P}$, showed the lowest responses $(<2 \mathrm{mg} / \mathrm{mL} \mathrm{t}$ $\mathrm{BOOH})$, and it seems highly unlikely for these PAHs to make any appreciable contribution to the oxidative stress of ambient $\mathrm{PM}_{2.5}$, as measured by the macrophage ROS assay. This is in contrast to several studies conducted on bronchial epithelial BEAS-2B cells (Landkocz et al., 2017), acute monocytic leukemia THP-1 cells (Den Hartigh et al., 2010) and U937 cell line (Tsai et al., 2012), which have suggested that PAHs such as B[a]A, B[a]P, pyrene, anthracene and phenanthrene are the important drivers of oxidative stress and cytotoxicity. However, these cells of human origin differ significantly from the murine cell lines used in our study in terms of their morphology (Krombach et al., 1997), expression of certain reactive nitrogen species and related enzymes (Jesch et al., 1997), and membrane proteins (Jaguin et al., 2013). Certain mechanisms, such as aryl hydrocarbon receptor (AhR)-mediated activity which activates the CYP450 gene, are necessary for the initial steps of bioactivation of PAHs (Rossner et al., 2020) to convert them into more redox-active products. It has also been shown that such mechanistic pathways differ substantially among different cells (Libalova et al., 2018; Vondráček et al., 2017). Therefore, a direct comparison between our results and those studies showing a significant role of PAHs in the oxidative stress is probably not reasonable.

Among the inorganic salts, $\mathrm{NH}_{4} \mathrm{NO}_{3}$ and $\mathrm{NH}_{4} \mathrm{SO}_{4}$ showed the lowest responses $(<1.5 \mathrm{mg} / \mathrm{mL} \mathrm{t}-\mathrm{BOOH})$. Although, the average response of chloride salts such as $\mathrm{KCl}, \mathrm{NaCl}, \mathrm{NH}_{4} \mathrm{Cl}$ and $\mathrm{CaCl}_{2}(3.22-2.34 \mathrm{mg} / \mathrm{mL}$ t-BOOH$)$ seems to be slightly higher than other salts, there was no significant difference in the responses ( $>0.05$; unpaired t-test) of any of these salts. Overall, at atmospherically relevant concentrations, inorganic salts seem to have very low contribution, if at all, to the oxidative stress as compared to the metals and quinones. This is consistent with previous studies based on ambient PM samples, showing either nil or inconsistent correlation of the macrophage ROS response with the concentration of inorganic ions (Hu et al., 2008; Kam et al., 2011; Verma et al., 2009; Wang et al., 2013; Xu et al., 2020).

\section{Conclusion}

In this paper, we have described the development of SCOPE for assessing the OP of water-soluble extracts of ambient PM in rat alveolar macrophages. The promising results of this instrument could pave the way for further development in automating other cellular assays. Moreover, since real-time instruments based on acellular OP assays have been developed in recent past, 
the current research opens up the road for the development of such online instruments based on mammalian cell lines, possibly coupling it to a real-time ambient PM sampling device (e.g., particle-into-liquid sampler or mist chamber). SCOPE is capable of analyzing up to 6 samples in a span of 5 hours without any manual intervention. The results of performance evaluation of the instrument demonstrate a high precision and accuracy for both positive control and the PM samples.

Overall, we have shown a first of its kind instrument capable of performing cellular OP measurements of PM. It substantially reduces the extent of manual labor associated with conducting cellular assays resulting in increased throughput of the results.

320 We demonstrated that SCOPE is capable of handling large number of ambient PM samples, thus, providing an opportunity for generating an extensive dataset on cellular OP, that can be used in epidemiological studies. We also generated a database of several chemical compounds commonly known to be present in the ambient PM. Metals such as Fe (II), Mn (II) and Cu (II) dominated the OP, which were followed by quinones such as PQN, 1,2-NQN and 1,4-NQN. PAHs and inorganic salts showed low OP as compared to the most metals and quinones. Further investigations on the interactions of these chemical species may

325 be undertaken in future studies.

Data availability. Supplementary data is provided with the manuscript.

Author contributions. SS developed the instrument, performed the experiments and prepared the manuscript. YW contributed 330 in filters collection, helped in developing the manual protocol for cell-based experiments and edited the manuscript. JVP helped in developing the instrument and edited the manuscript. VV conceived the idea, organized the manuscript and supervised the overall project.

Competing interests. The authors declare that they have no conflict of interest.

Acknowledgments. This work was supported by the National Science Foundation under Grant No. CBET-1847237. We thank Sandra McMasters, the director of cell media facility at UIUC for providing us NR8383 Cell Culture and media. 


\section{References}

Alfano, R., Herceg, Z., Nawrot, T. S., Chadeau-Hyam, M., Ghantous, A., and Plusquin, M.: The Impact of Air Pollution on

Our Epigenome: How Far Is the Evidence? (A Systematic Review), Curr. Environ. Health Rep., 5(4), 544-578, https://doi.org/10.1007/s40572-018-0218-8, 2018.

Berg, K. E., Clark, K. M., Li, X., Carter, E. M., Volckens, J., and Henry, C. S.: High-throughput, semi-automated dithiothreitol (DTT) assays for oxidative potential of fine particulate matter, Atmos. Environ., 222, 117132, https://doi.org/10.1016/j.atmosenv.2019.117132, 2020.

Brehmer, C., Lai, A., Clark, S., Shan, M., Ni, K., Ezzati, M., Yang, X., Baumgartner, J., Schauer, J. J., and Carter, E.: The Oxidative Potential of Personal and Household $\mathrm{PM}_{2.5}$ in a Rural Setting in Southwestern China. Environ. Sci. and Technol., 53(5), 2788-2798, https://doi.org/10.1021/acs.est.8b05120, 2019.

Breitner, S., Peters, A., Zareba, W., Hampel, R., Oakes, D., Wiltshire, J., Frampton, M. W., Hopke, P. K., Cyrys, J., Utell, M. J., Kane, C., Schneider, A., and Rich, D. Q.: Ambient and controlled exposures to particulate air pollution and acute changes in heart rate variability and repolarization, Sci. Rep., 9(1), 1-12, https://doi.org/10.1038/s41598-019-38531-9, 2019.

Brömme, H. J., Zühlke, L., Silber, R. E., and Simm, A.: DCFH2 interactions with hydroxyl radicals and other oxidants Influence of organic solvents, Exp. Gerontol., 43(7), 638-644, https://doi.org/10.1016/j.exger.2008.01.010, 2008.

Brown, A. R., Stevanovic, S., Bottle, S., and Ristovski, D. Z.: An instrument for the rapid quantification of PM-bound ROS: The Particle into Nitroxide Quencher (PINQ), Atmos. Meas. Tech., 12(4), 2387-2401, https://doi.org/10.5194/amt-12-23872019, 2019.

Castro-Alférez, M., Polo-López, M. I., and Fernández-Ibáñez, P.: Intracellular mechanisms of solar water disinfection, Sci. Rep., 6(1), 1-10, https://doi.org/10.1038/srep38145, 2016.

Charrier, J. G., and Anastasio, C. (2012).: On dithiothreitol (DTT) as a measure of oxidative potential for ambient particles:

Evidence for the importance of soluble Inewline transition metals, Atmos. Chem. Phys., 12(19), 9321-9333, 365 https://doi.org/10.5194/acp-12-9321-2012, 2012.

Chen, F., Vallyathan, V., Castranova, V., and Shi, X.: Cell apoptosis induced by carcinogenic metals, Mol. Cell. Biochem., 222(1-2), 183-188, https://doi.org/10.1023/A:1017970330982, 2001.

Chen, X., Zhong, Z., Xu, Z., Chen, L., and Wang, Y.: 2',7'-Dichlorodihydrofluorescein as a fluorescent probe for reactive oxygen species measurement: Forty years of application and controversy, Free Radic. Res., 44(6), 587-604, https://doi.org/10.3109/10715761003709802, 2010.

Cheung, K., Shafer, M. M., Schauer, J. J., and Sioutas, C.: Diurnal trends in oxidative potential of coarse particulate matter in the Los Angeles basin and their relation to sources and chemical composition, Environ. Sci. Technol., 46(7), 3779-3787, https://doi.org/10.1021/es204211v, 2012. 
Crobeddu, B., Aragao-Santiago, L., Bui, L. C., Boland, S., and Baeza Squiban, A.: Oxidative potential of particulate matter

2.5 as predictive indicator of cellular stress, Environ. Pollut., 230, 125-133, https://doi.org/10.1016/j.envpol.2017.06.051, 2017.

Delfino, R. J., Staimer, N., Tjoa, T., Gillen, D. L., Schauer, J. J., and Shafer, M. M.: Airway inflammation and oxidative potential of air pollutant particles in a pediatric asthma panel, J. Expo. Sc. Environ. Epidemiol., 23(5), 466-473, https://doi.org/10.1038/jes.2013.25, 2013.

Den Hartigh, L. J., Lamé, M. W., Ham, W., Kleeman, M. J., Tablin, F., and Wilson, D. W.: Endotoxin and polycyclic aromatic hydrocarbons in ambient fine particulate matter from Fresno, California initiate human monocyte inflammatory responses mediated by reactive oxygen species, Toxicol.in Vitro, 24(7), 1993-2002, https://doi.org/10.1016/j.tiv.2010.08.017, 2010.

Dikalov, S. I., and Harrison, D. G.: Methods for detection of mitochondrial and cellular reactive oxygen species, Antioxid. Redox Signal., 20(2), 372-382, https://doi.org/10.1089/ars.2012.4886, 2014.

Doble, M., Venkatachalam, G., and Arumugam, S.: Synthesis, characterization, and biological activity of aminated zymosan, ACS Omega, 5(26), 15973-15982, https://doi.org/10.1021/acsomega.0c01243, 2020.

Doiron, D., de Hoogh, K., Probst-Hensch, N., Mbatchou, S., Eeftens, M., Cai, Y., Schindler, C., Fortier, I., Hodgson, S., Gaye, A., Stolk, R., and Hansell, A.: Residential air pollution and associations with wheeze and shortness of breath in adults: A combined analysis of cross-sectional data from two large European cohorts, Environ. Health Perspect., 125(9), 1-10. https://doi.org/10.1289/EHP1353, 2017.

Fang, T., Verma, V., Guo, H., King, L. E., Edgerton, E. S., and Weber, R. J.: A semi-automated system for quantifying the oxidative potential of ambient particles in aqueous extracts using the dithiothreitol (DTT) assay: Results from the Southeastern Center for Air Pollution and Epidemiology (SCAPE), Atmos. Meas. Tech., 8(1), 471-482, https://doi.org/10.5194/amt-8-471$2015,2015$.

395 Fatemi, N., Sanati, M. H., Jamali Zavarehei, M., Ayat, H., Esmaeili, V., Golkar-Narenji, A., Zarabi, M., and Gourabi, H.: Effect of tertiary-butyl hydroperoxide (TBHP)-induced oxidative stress on mice sperm quality and testis histopathology, Andrologia, 45(4), 232-239. https://doi.org/10.1111/j.1439-0272.2012.01335.x, 2013.

Gao, D., Fang, T., Verma, V., Zeng, L., and Weber, R. J.: A method for measuring total aerosol oxidative potential (OP) with the dithiothreitol (DTT) assay and comparisons between an urban and roadside site of water-soluble and total OP, Atmos. 400 Meas. Tech., 10(8), 2821-2835, https://doi.org/10.5194/amt-10-2821-2017, 2017.

Gao, Y., Jiang, R., Qie, J., Chen, Y., Xu, D., Liu, W., and Gao, Q.: Studies on the characteristic and activity of low-molecular fragments from zymosan, Carbohydr. Polym., 90(4), 1411-1414, https://doi.org/10.1016/j.carbpol.2012.05.096, 2012.

Helmke, R. J., Boyd, R. L., German, V. F., and Mangos, J. A.: From growth factor dependence to growth factor responsiveness: The genesis of an alveolar macrophage cell line, In Vitro Cellular Dev. Biol., 23(8), 567-574, 405 https://doi.org/10.1007/BF02620974, 1987. 
Holm, S. M., Balmes, J., Gillette, D., Hartin, K., Seto, E., Lindeman, D., Polanco, D., and Fong, E.: Cooking behaviors are related to household particulate matter exposure in children with asthma in the urban East Bay Area of Northern California, PLoS ONE, 13(6), 1-15, https://doi.org/10.1371/journal.pone.0197199, 2018.

Hu, S., Polidori, A., Arhami, M., Shafer, M. M., Schauer, J. J., Cho, A., and Sioutas, C.: Redox activity and chemical speciation of size fractioned PM in the communities of the Los Angeles-Long Beach harbor, Atmos. Chem. Phys., 8(21), 6439-6451, https://doi.org/10.5194/acp-8-6439-2008, 2008.

Huang, W., Zhang, Y., Zhang, Y., Zeng, L., Dong, H., Huo, P., Fang D. and Schauer, J. J.: Development of an automated sampling-analysis system for simultaneous measurement of reactive oxygen species (ROS) in gas and particle phases: GACROS, Atmos. Environ., 134, 18-26, https://doi.org/10.1016/j.atmosenv.2016.03.038, 2016.

415 Jaguin, M., Houlbert, N., Fardel, O., and Lecureur, V.: Polarization profiles of human M-CSF-generated macrophages and comparison of M1-markers in classically activated macrophages from GM-CSF and M-CSF origin, Cell. Immunol., 281(1), 51-61, https://doi.org/10.1016/j.cellimm.2013.01.010, 2013.

Janssen, N. A. H., Strak, M., Yang, A., Hellack, B., Kelly, F. J., Kuhlbusch, T. A. J., Harrison, R. M., Brunekreef, B., Cassee, F. R., Steenhof, M., and Hoek, G.: Associations between three specific a-cellular measures of the oxidative potential of particulate matter and markers of acute airway and nasal inflammation in healthy volunteers, Occup. Environ. Med., 72(1), 49-56, https://doi.org/10.1136/oemed-2014-102303, 2015.

Jesch, N. K., Dörger, M., Enders, G., Rieder, G., Vogelmeier, C., Messmer, K., and Krombach, F.: Expression of inducible nitric oxide synthase and formation of nitric oxide by alveolar macrophages: an interspecies comparison, Environ. Health Perspect., 105(suppl 5), 1297-1300, https://doi.org/10.1289/ehp.97105s51297, 1997.

425 Kalyanaraman, B., Darley-Usmar, V., Davies, K. J., Dennery, P. A., Forman, H. J., Grisham, M. B., Mann, G.E., Moore, K., Roberts II, L.J., and Ischiropoulos, H.: Measuring reactive oxygen and nitrogen species with fluorescent probes: challenges and limitations, Free Radic. Biol. Med., 52(1), 1-6, https://doi.org/10.1016/j.freeradbiomed.2011.09.030, 2012.

Kam, W., Ning, Z., Shafer, M. M., Schauer, J. J. and Sioutas, C.: Chemical characterization and redox potential of coarse and fine particulate matter (PM) in underground and ground-level rail systems of the Los Angeles Metro, Environ. Sci. and 430 Technol., 45(16), 6769-6776, https://doi.org/10.1021/es201195e, 2011.

Karakatsani, A., Analitis, A., Perifanou, D., Ayres, J. G., Harrison, R. M., Kotronarou, A., Kavouras, I. G., Pekkanen, J., Hämeri, K., Kos, G. P., De Hartog, J. J., Hoek, G., and Katsouyanni, K.: Particulate matter air pollution and respiratory symptoms in individuals having either asthma or chronic obstructive pulmonary disease: A European multicentre panel study, Environ. Health 11(1), 1-16, https://doi.org/10.1186/1476-069X-11-75, 2012.

435 Klein, C. B., Su, L., Bowser, D., and Leszcynska, J.: Chromate-induced epimutations in mammalian cells, Environ. Health Perspect., 110(Suppl. 5), 739-743, https://doi.org/10.1289/ehp.02110s5739, 2002.

Klotz, L. O., Hou, X., and Jacob, C.: 1,4-naphthoquinones: From oxidative damage to cellular and inter-cellular signaling, Molecules, 19(9), 14902-14918, https://doi.org/10.3390/molecules190914902, 2014. 
https://doi.org/10.5194/amt-2021-188

Preprint. Discussion started: 22 July 2021

(C) Author(s) 2021. CC BY 4.0 License.
Atmospheric

Measurement

Techniques

Discussions

Krombach, F., Münzing, S., Allmeling, A. M., Gerlach, J. T., Behr, J., and Dörger, M.: Cell size of alveolar macrophages: an

interspecies comparison, Environ. Health Perspect., 105 Suppl 5(September), 1261-1263, https://doi.org/10.1289/ehp.97105s51261, 1997.

Kryston, T. B., Georgiev, A. B., Pissis, P., and Georgakilas, A. G.: Role of oxidative stress and DNA damage in human carcinogenesis, Mutat. Res., 711(1-2), 193-201, https://doi.org/10.1016/j.mrfmmm.2010.12.016, 2011.

Kučera, O., Endlicher, R., Roušar, T., Lotková, H., Garnol, T., Drahota, Z., and Červinková, Z.: The effect of tert -butyl hydroperoxide-induced oxidative stress on lean and steatotic rat hepatocytes in vitro, Oxid. Med. Cell. Longev., 2014, https://doi.org/10.1155/2014/752506, 2014.

Künzli, N., Mudway, I. S., Götschi, T., Shi, T., Kelly, F. J., Cook, S., Burney, P., Forsberg, B., Gauderman, J. W., Hazenkamp, M. E., Heinrich, J., Jarvis, D., Norbäck, D., Payo-Losa, F., Poli, A., Sunyer, J., and Borm, P. J. A.: Comparison of oxidative properties, light absorbance, and total and elemental mass concentration of ambient $\mathrm{PM}_{2.5}$ collected at 20 European sites, Environ. Health Perspect., 114(5), 684-690, https://doi.org/10.1289/ehp.8584, 2006.

Kuznetsov, A. V., Kehrer, I., Kozlov, A. V., Haller, M., Redl, H., Hermann, M., Grimm, M., and Troppmair, J.: Mitochondrial ROS production under cellular stress: Comparison of different detection methods, Anal. Bioanal. Chem., 400(8), 2383-2390, https://doi.org/10.1007/s00216-011-4764-2, 2011.

Landkocz, Y., Ledoux, F., André, V., Cazier, F., Genevray, P., Dewaele, D., Martin, P. J., Lepers, C., Verdin, A., Courcot, L.,

Boushina, S., Sichel, F., Gualtieri, M., Shirali, P., Courcot, D., and Billet, S.: Fine and ultrafine atmospheric particulate matter at a multi-influenced urban site: Physicochemical characterization, mutagenicity and cytotoxicity, Environ. Pollut., 221, 130140, https://doi.org/10.1016/j.envpol.2016.11.054, 2017.

Landreman, A. P., Shafer, M. M., Hemming, J. C., Hannigan, M. P., and Schauer, J. J.: A macrophage-based method for the assessment of the reactive oxygen species (ROS) activity of atmospheric particulate matter (PM) and application to routine (daily-24 h) aerosol monitoring studies, Aerosol Sci Technol., 42(11), 946-957, https://doi.org/10.1080/02786820802363819, 2008.

Lane, K. B., Egan, B., Vick, S., Abdolrasulnia, R., and Shepherd, V. L.: Characterization of a rat alveolar macrophage cell line that expresses a functional mannose receptor, J. Leukoc. Biol., 64(3), 345-350, https://doi.org/10.1002/jlb.64.3.345, 1998.

LeBel, C. P., Ischiropoulos, H., and Bondy, S. C.: Evaluation of the Probe 2',7'-Dichlorofluorescin as an Indicator of Reactive Oxygen Species Formation and Oxidative Stress, Chem. Res. Toxicol., 5(2), 227-231, https://doi.org/10.1021/tx00026a012, 1992.

Lee, J. H., and Hopke, P. K.: Apportioning sources of $\mathrm{PM}_{2.5}$ in St. Louis, MO using speciation trends network data, Atmos. Environ., 40(suppl. 2), 360-377, https://doi.org/10.1016/j.atmosenv.2005.11.074, 2006.

Li, N., Xia, T. and Nel, A. E.: The role of oxidative stress in ambient particulate matter-induced lung diseases and its 470 implications in the toxicity of engineered nanoparticles, Free Radic. Biol. Med., 44(9), 1689-1699, https://dx.doi.org/10.1016/j.freeradbiomed.2008.01.028, 2008. 
Libalova, H., Milcova, A., Cervena, T., Vrbova, K., Rossnerova, A., Novakova, Z., Topinka, J., and Rossner, P.: Kinetics of ROS generation induced by polycyclic aromatic hydrocarbons and organic extracts from ambient air particulate matter in model human lung cell lines, Mutat. Res., 827(January), 50-58, https://doi.org/10.1016/j.mrgentox.2018.01.006, 2018.

Lin, T. J., Hirji, N., Stenton, G. R., Gilchrist, M., Grill, B. J., Schreiber, A. D., and Befus, A. D.: Activation of macrophage CD8: pharmacological studies of TNF and IL-1 $\beta$ production, J. Immunol., 164(4), 1783-1792, https://doi.org/10.4049/jimmunol.164.4.1783, 2000.

Lopes, V. R., Sanchez-Martinez, C., Strømme, M., and Ferraz, N.: In vitro biological responses to nanofibrillated cellulose by human dermal, lung and immune cells: Surface chemistry aspect, Part. Fibre Toxicol., 14(1), 1-13, https://doi.org/10.1186/s12989-016-0182-0, 2017.

Møller, P., Jacobsen, N. R., Folkmann, J. K., Danielsen, P. H., Mikkelsen, L., Hemmingsen, J. G., Vesterdal, L. K., Forchhammer, L., Wallin, H., and Loft, S.: Role of oxidative damage in toxicity of particulate, Free Radic. Res., 44(1), 1-46. https://doi.org/10.3109/10715760903300691, 2010.

Mudway, I. S., Duggan, S. T., Venkataraman, C., Habib, G., Kelly, F. J., and Grigg, J.: Combustion of dried animal dung as biofuel results in the generation of highly redox active fine particulates, Part. Fibre Toxicol., 2, 1-11, https://doi.org/10.1186/1743-8977-2-6, 2005.

Myhre, O., Andersen, J. M., Aarnes, H., and Fonnum, F.: Evaluation of the probes 2',7'-dichlorofluorescin diacetate, luminol, and lucigenin as indicators of reactive species formation, Biochem. Pharmacol., 65(10), 1575-1582, https://doi.org/10.1016/S0006-2952(03)00083-2, 2003.

OECD/SIDS (1995), Screening Information Data Set (SIDS) for High Production Volume Chemicals, OECD Initial Assessment, IRPTC/UNEP, Volume 1, Part 2, Organization for Economic Co-operation and Development

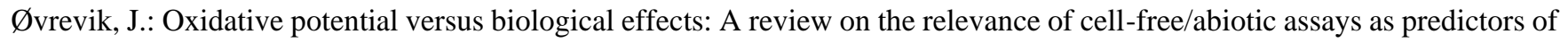
toxicity from airborne particulate matter, Int. J. Mol. Sci., 20(19), https://doi.org/10.3390/ijms20194772, 2019.

Pieters, N., Plusquin, M., Cox, B., Kicinski, M., Vangronsveld, J., and Nawrot, T. S.: An epidemiological appraisal of the association between heart rate variability and particulate air pollution: A meta-analysis, Heart, 98(15), 1127-1135, https://doi.org/10.1136/heartjnl-2011-301505, 2012.

Pope, C. A., Burnett, R. T., Thurston, G. D., Thun, M. J., Calle, E. E., Krewski, D., and Godleski, J. J.: Cardiovascular Mortality and Long-Term Exposure to Particulate Air Pollution: Epidemiological Evidence of General Pathophysiological Pathways of Disease, Circulation, 109(1), 71-77, https://doi.org/10.1161/01.CIR.0000108927.80044.7F, 2004.

500 Prasad, D., Ram, M. S., Sawhney, R. C., Ilavazhagan, G., and Banerjee, P. K.: Mechanism of tert-butylhydroperoxide induced cytotoxicity in U-937 macrophages by alteration of mitochondrial function and generation of ROS, Toxicol. In Vitro, 21(5), 846-854, https://doi.org/10.1016/j.tiv.2007.02.007, 2007.

Puthussery, J. V., Zhang, C., and Verma, V.: Development and field testing of an online instrument for measuring the realtime oxidative potential of ambient particulate matter based on dithiothreitol assay, Atmos. Meas. Tech., 11(10), 5767-5780, https://doi.org/10.5194/amt-11-5767-2018, 2018. 
Rao, X., Zhong, J., Brook, R. D. and Rajagopalan, S.: Effect of particulate matter air pollution on cardiovascular oxidative stress pathways, Antioxid. Redox Signal, 28(9), 797-818, https://dx.doi.org/10.1089/ars.2017.7394, 2018.

Reuter, S., Gupta, S. C., Chaturvedi, M. M., and Aggarwal, B. B.: Oxidative stress, inflammation, and cancer: How are they linked?, Free Radic. Biol. Med., 49(11), 1603-1616, https://doi.org/10.1016/j.freeradbiomed.2010.09.006, 2010.

Riojas-Rodríguez, H., Escamilla-Cejudo, J. A., González-Hermosillo, J. A., Téllez-Rojo, M. M., Vallejo, M., Santos-Burgoa, C., and Rojas-Bracho, L.: Personal $\mathrm{PM}_{2.5}$ and $\mathrm{CO}$ exposures and heart rate variability in subjects with known ischemic heart disease in Mexico City, J. Expo. Sci. Environ. Epidemiol., 16(2), 131-137. https://doi.org/10.1038/sj.jea.7500453, 2006.

Rosenkranz, A. R., Schmaldienst, S., Stuhlmeier, K. M., Chen, W., Knapp, W., and Zlabinger, G. J.: A microplate assay for the detection of oxidative products using 2', 7'-dichlorofluorescin-diacetate, J. Immunol. Methods, 156(1), 39-45, https://doi.org/10.1016/0022-1759(92)90008-h, 1992.

Rossner, P., Libalova, H., Vrbova, K., Cervena, T., Rossnerova, A., Elzeinova, F., Milcova, A., Novakova, Z., and Topinka, J.: Genotoxicant exposure, activation of the aryl hydrocarbon receptor, and lipid peroxidation in cultured human alveolar type II A549 cells, Mutat. Res., 853(April), 503173, https://doi.org/10.1016/j.mrgentox.2020.503173, 2020.

Roux, C., Jafari, S. M., Shinde, R., Duncan, G., Cescon, D. W., Silvester, J., Chu, M. F., Hodgson, K., Berger, T., Wakeham, 520 A., Palomero, L., Garcia-Valero, M., Pujana, M. A., Mak, T. W., McGaha, T. L., Cappello, P., and Gorrini, C.: Reactive oxygen species modulate macrophage immunosuppressive phenotype through the up-regulation of PD-L1, PNAS, 116(10), 4326-4335, https://doi.org/10.1073/pnas.1819473116, 2019.

Sameenoi, Y., Koehler, K., Shapiro, J., Boonsong, K., Sun, Y., Collett Jr, J., Volckens J. and Henry, C. S.: Microfluidic electrochemical sensor for on-line monitoring of aerosol oxidative activity, J. Am. Chem. Soc., 134(25), 10562-10568, https://doi.org/10.1021/ja3031104, 2012.

Shang, Y., Zhang, L., Jiang, Y., Li, Y., and Lu, P.: Airborne quinones induce cytotoxicity and DNA damage in human lung epithelial A549 cells: The role of reactive oxygen species, Chemosphere, 100, 42-49, https://doi.org/10.1016/j.chemosphere.2013.12.079, 2014.

Shinkai, Y., Iwamoto, N., Miura, T., Ishii, T., Cho, A. K., and Kumagai, Y.: Redox cycling of 1,2-naphthoquinone by thioredoxin1 through Cys32 and Cys35 causes inhibition of its catalytic activity and activation of ASK1/p38 signaling, Chem. Res. Toxicol., 25(6), 1222-1230, https://doi.org/10.1021/tx300069r, 2012.

Sigola, L. B., Fuentes, A. L., Millis, L. M., Vapenik, J., and Murira, A.: Effects of Toll-like receptor ligands on RAW 264.7 macrophage morphology and zymosan phagocytosis, Tissue Cell, 48(4), 389-396, https://doi.org/10.1016/j.tice.2016.04.002, 2016.

535 Steenhof, M., Gosens, I., Strak, M., Godri, K. J., Hoek, G., Cassee, F. R., Mudway, I. S., Kelly, F. J., Harrison, R. M., Lebret, E., Brunekreef, B., Janssen, N. A. H., and Pieters, R. H. H.: In vitro toxicity of particulate matter (PM) collected at different sites in the Netherlands is associated with PM composition, size fraction and oxidative potential - the RAPTES project, Part. Fibre Toxicol., 8, 1-15, https://doi.org/10.1186/1743-8977-8-26, 2011. 
https://doi.org/10.5194/amt-2021-188

Preprint. Discussion started: 22 July 2021

(c) Author(s) 2021. CC BY 4.0 License.
Atmospheric

Measurement

Techniques

Discussions

Sun, J., Wang, S., Zhao, D., Hun, F. H., Weng, L., and Liu, H.: Cytotoxicity, permeability, and inflammation of metal oxide nanoparticles in human cardiac microvascular endothelial cells: Cytotoxicity, permeability, and inflammation of metal oxide nanoparticles, Cell Biol. Toxicol., 27(5), 333-342, https://doi.org/10.1007/s10565-011-9191-9, 2011.

Sung, S. S. J., Nelson, R. S., and Silverstein, S. C.: Yeast mannans inhibit binding and phagocytosis of zymosan by mouse peritoneal macrophages, J. Cell Biol., 96(1), 160-166, https://doi.org/10.1083/jcb.96.1.160, 1983.

Thayyullathil, F., Chathoth, S., Hago, A., Patel, M., and Galadari, S.: Rapid reactive oxygen species (ROS) generation induced

545 by curcumin leads to caspase-dependent and -independent apoptosis in L929 cells, Free Radic. Biol. Med., 45(10), 1403-1412, https://doi.org/10.1016/j.freeradbiomed.2008.08.014, 2008.

Thomas, M. G., Marwood, R. M., Parsons, A. E., and Parsons, R. B.: The effect of foetal bovine serum supplementation upon the lactate dehydrogenase cytotoxicity assay: Important considerations for in vitro toxicity analysis, Toxicol. In Vitro, 30(1), 300-308, https://doi.org/ 10.1016/j.tiv.2015.10.007, 2015.

550 Tsai, J. H., Chen, S. J., Huang, K. L., Lin, T. C., Chaung, H. C., Chiu, C. H., Chiu, J. Y., Lin, C. C., and Tsai, P. Y.: PM, carbon, PAH, and particle-extract-induced cytotoxicity Emissions from a diesel generator fueled with waste-edible-oilbiodiesel, Aerosol Air Qual. Res., 12(5), 843-855, https://doi.org/10.4209/aaqr.2012.07.0181, 2012.

Underhill, D. M.: Macrophage recognition of zymosan particles, J. Endotoxin Res., 9(3), 176-180, https://doi.org/10.1179/096805103125001586, 2003.

555 Venkatachalam, G., Arumugam, S., and Doble, M.: Synthesis, Characterization, and Biological Activity of Aminated Zymosan, ACS omega, 5(26), 15973-15982, https://doi.org/10.1021/acsomega.0c01243, 2020.

Venkatachari, P., and Hopke, P. K.: Development and laboratory testing of an automated monitor for the measurement of atmospheric particle-bound reactive oxygen species (ROS), Aerosol Sci. Technol., 42(8), 629-635, https://doi.org/10.1080/02786820802227345, 2008.

560 Verma, V., Ning, Z., Cho, A. K., Schauer, J. J., Shafer, M. M., and Sioutas, C.: Redox activity of urban quasi-ultrafine particles from primary and secondary sources, Atmos. Environ., 43(40), 6360-6368, https://doi.org/10.1016/j.atmosenv.2009.09.019, 2009.

Vidrio, E., Phuah, C. H., Dillner, A. M., \& Anastasio, C.: Generation of hydroxyl radicals from ambient fine particles in a surrogate lung fluid solution, Environ. Sci. and Technol., 43(3), 922-927, https://doi.org/10.1021/es801653u, 2009.

565 Visentin, M., Pagnoni, A., Sarti, E., and Pietrogrande, M. C.: Urban PM 2.5 oxidative potential: Importance of chemical species and comparison of two spectrophotometric cell-free assays, Environ. Pollut., 219, 72-79, https://doi.org/10.1016/j.envpol.2016.09.047, 2016.

Vondráček, J., Pěnčíková, K., Neča, J., Ciganek, M., Grycová, A., Dvořák, Z., and Machala, M.: Assessment of the aryl hydrocarbon receptor-mediated activities of polycyclic aromatic hydrocarbons in a human cell-based reporter gene assay,

570 Environ. Pollut., 220, 307-316, https://doi.org/10.1016/j.envpol.2016.09.064, 2017.

Wan, C. P., Myung, E., and Lau, B. H. S.: An automated micro-fluorometric assay for monitoring oxidative burst activity of phagocytes, J. Immunol. Methods, 159(1-2), 131-138, https://doi.org/10.1016/0022-1759(93)90150-6, 1993. 
https://doi.org/10.5194/amt-2021-188

Preprint. Discussion started: 22 July 2021

(C) Author(s) 2021. CC BY 4.0 License.
Atmospheric

Measurement

Techniques

Discussions

Wan, R., Mo, Y., Feng, L., Chien, S., Tollerud, D. J., and Zhang, Q.: DNA damage caused by metal nanoparticles: Involvement of oxidative stress and activation of ATM, Chem. Res. Toxicol., 25(7), 1402-1411, https://doi.org/10.1021/tx200513t, 2012.

Wang, D., Pakbin, P., Shafer, M. M., Antkiewicz, D., Schauer, J. J., and Sioutas, C.: Macrophage reactive oxygen species activity of water-soluble and water-insoluble fractions of ambient coarse, $\mathrm{PM}_{2.5}$ and ultrafine particulate matter (PM) in Los Angeles, Atmos.Environ., 77, 301-310, https://doi.org/10.1016/j.atmosenv.2013.05.031, 2013.

Wang, Y., Puthussery, J. V., Yu, H., and Verma, V.: Synergistic and antagonistic interactions among organic and metallic components of the ambient particulate matter (PM) for the cytotoxicity measured by Chinese hamster ovary cells, Sci. Total Environ., 736, 139511, https://doi.org/10.1016/j.scitotenv.2020.139511, 2020.

Wang, Z., Li, N., Zhao, J., White, J. C., Qu, P., and Xing, B.: CuO nanoparticle interaction with human epithelial cells: Cellular uptake, location, export, and genotoxicity, Chem. Res. Toxicol., 25(7), 1512-1521, https://doi.org/10.1021/tx3002093, 2012. Wragg, F. P. H., Fuller, S. J., Freshwater, R., Green, D. C., Kelly, F. J., and Kalberer, M.: An automated online instrument to quantify aerosol-bound reactive oxygen species (ROS) for ambient measurement and health-relevant aerosol studies. Atmos. Meas. Tech., 9(10), 4891-4900, https://doi.org/10.5194/amt-9-4891-2016, 2016.

Wu, J., Zhong, T., Zhu, Y., Ge, D., Lin, X., and Li, Q.: Effects of particulate matter (PM) on childhood asthma exacerbation and control in Xiamen, China, BMC Pediatr., 19(1), 1-11, https://doi.org/10.1186/s12887-019-1530-7, 2019.

Xiong, Q., Yu, H., Wang, R., Wei, J., and Verma, V.: Rethinking Dithiothreitol-Based Particulate Matter Oxidative Potential: Measuring Dithiothreitol Consumption versus Reactive Oxygen Species Generation. Environ. Sci. and Technol., 51(11), 65076514, https://doi.org/10.1021/acs.est.7b01272, 2017.

Xu, F., Shi, X., Qiu, X., Jiang, X., Fang, Y., Wang, J., Hu, D. and Zhu, T.: Investigation of the chemical components of ambient fine particulate matter (PM2. 5) associated with in vitro cellular responses to oxidative stress and inflammation, Environ. Int., 136, 105475, https://doi.org/10.1016/j.envint.2020.105475, 2020.

Yang, B. Y., Guo, Y., Morawska, L., Bloom, M. S., Markevych, I., Heinrich, J., Dharmage, S. C., Knibbs, L. D., Lin, S., Yim, 595 S. H. L., Chen, G., Li, S., Zeng, X. W., Liu, K. K., Hu, L. W., and Dong, G. H.: Ambient PM1 air pollution and cardiovascular disease prevalence: Insights from the 33 Communities Chinese Health Study, Environ. Int., 123, 310-317, https://doi.org/10.1016/j.envint.2018.12.012, 2019.

Yang, M., Ahmed, H., Wu, W., Jiang, B., and Jia, Z.: Cytotoxicity of Air Pollutant 9,10-Phenanthrenequinone: Role of Reactive Oxygen Species and Redox Signaling, BioMed Res. Int., 2018, https://doi.org/10.1155/2018/9523968, 2018.

$600 \mathrm{Yu}$, H., Puthussery, J. V., and Verma, V.: A semi-automated multi-endpoint reactive oxygen species activity analyzer (SAMERA) for measuring the oxidative potential of ambient $\mathrm{PM}_{2.5}$ aqueous extracts, Aerosol Sci. and Technol., 54(3), 304320, https://doi.org/10.1080/02786826.2019.1693492, 2019.

Yu, H., Wei, J., Cheng, Y., Subedi, K., and Verma, V.: Synergistic and Antagonistic Interactions among the Particulate Matter Components in Generating Reactive Oxygen Species Based on the Dithiothreitol Assay, Environ. Sci. and Technol., 52(4), 
https://doi.org/10.5194/amt-2021-188

Preprint. Discussion started: 22 July 2021

(c) Author(s) 2021. CC BY 4.0 License.
Atmospheric

Measurement

Techniques

Discussions

Zhou, J., Bruns, E. A., Zotter, P., Stefenelli, G., Prévôt, A. S. H., Baltensperger, U., El-Haddad, I., and Dommen, J.: Development, characterization and first deployment of an improved online reactive oxygen species analyzer, Atmos. Meas. Tech., 11, 65-80, https://doi.org/10.5194/amt-11-65-2018, 2018.

Zmirou, D., Gauvin, S., Pin, I., Momas, I., Just, J., Sahraoui, F., Moullec, Y.L., Bremont, F., Cassadou, S., Albertini, M.,

Lauvergne, N., Chiron, M., and Labbe, A.: Five epidemiological studies on transport and asthma: objectives, design and descriptive results, J. Exp. Sci. Environ. Epidemiol., 12(3), 186-196, https://doi.org/10.1038/sj.jea.7500217, 2002.

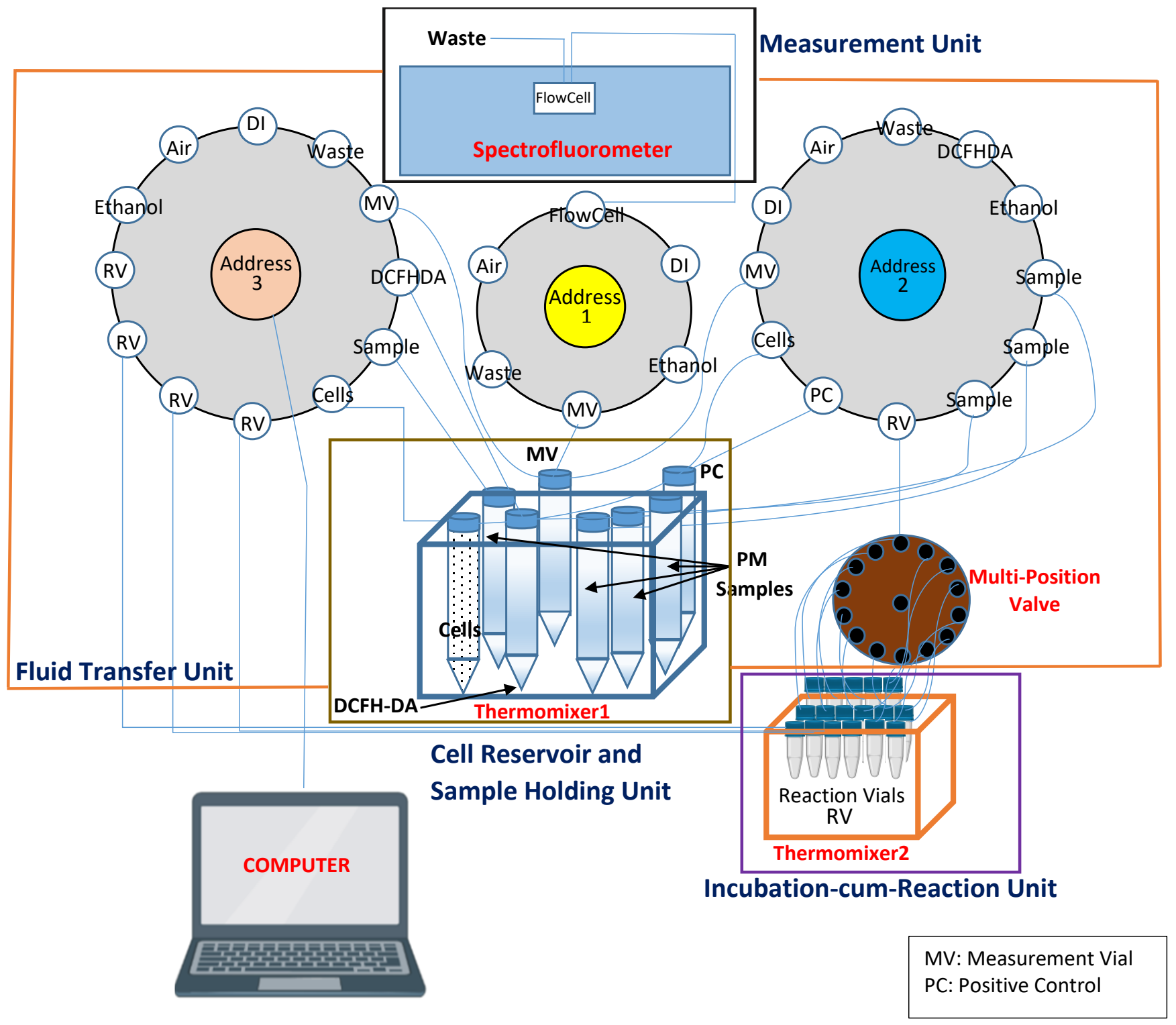

Figure 1: Automated System Setup. 
https://doi.org/10.5194/amt-2021-188

Preprint. Discussion started: 22 July 2021

(c) Author(s) 2021. CC BY 4.0 License.
Atmospheric Measurement Techniques Discussions

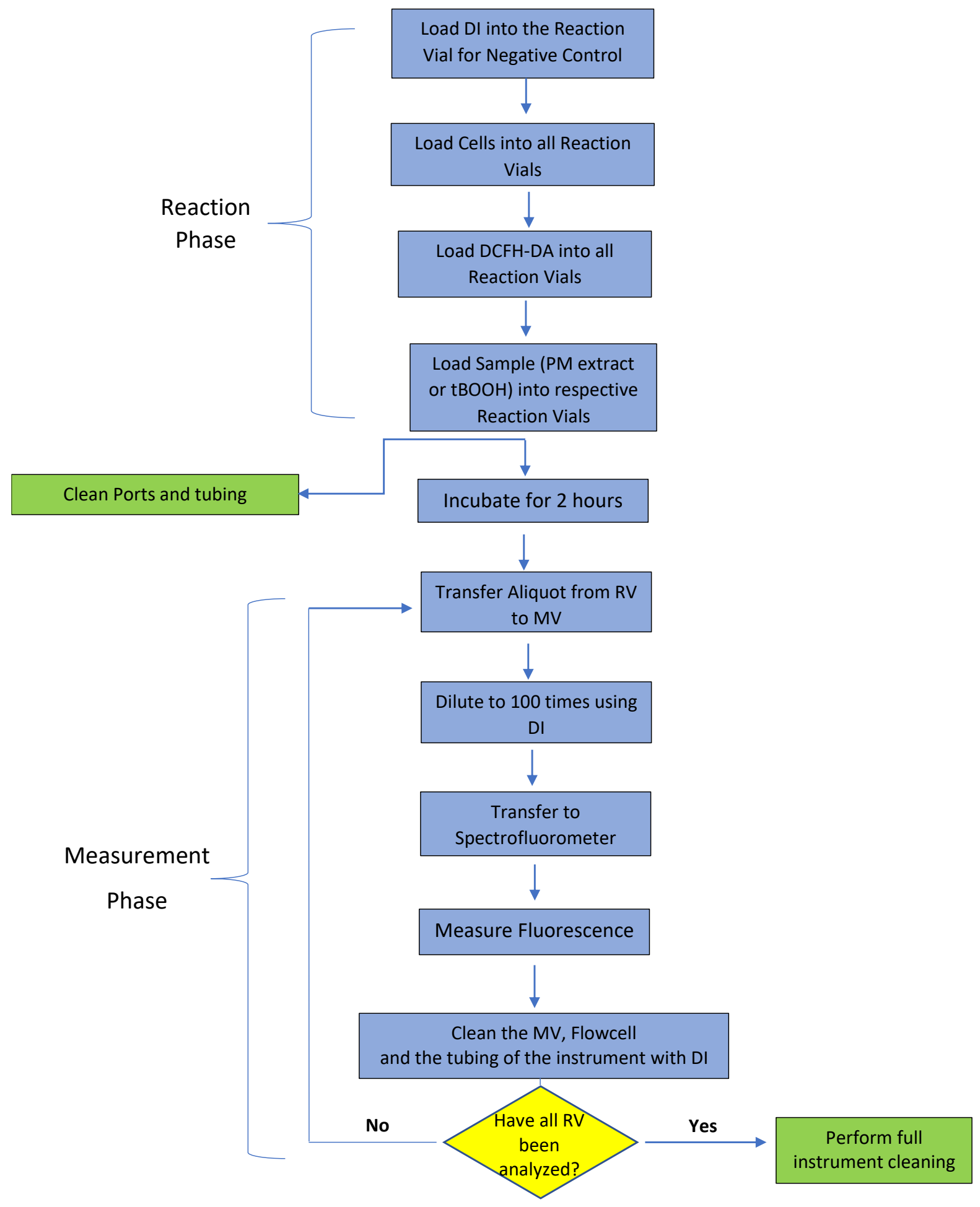


https://doi.org/10.5194/amt-2021-188

Preprint. Discussion started: 22 July 2021

(c) Author(s) 2021. CC BY 4.0 License.

\section{Atmospheric Measurement \\ Techniques

615 Figure 2: Algorithm for the instrument's operational protocol.

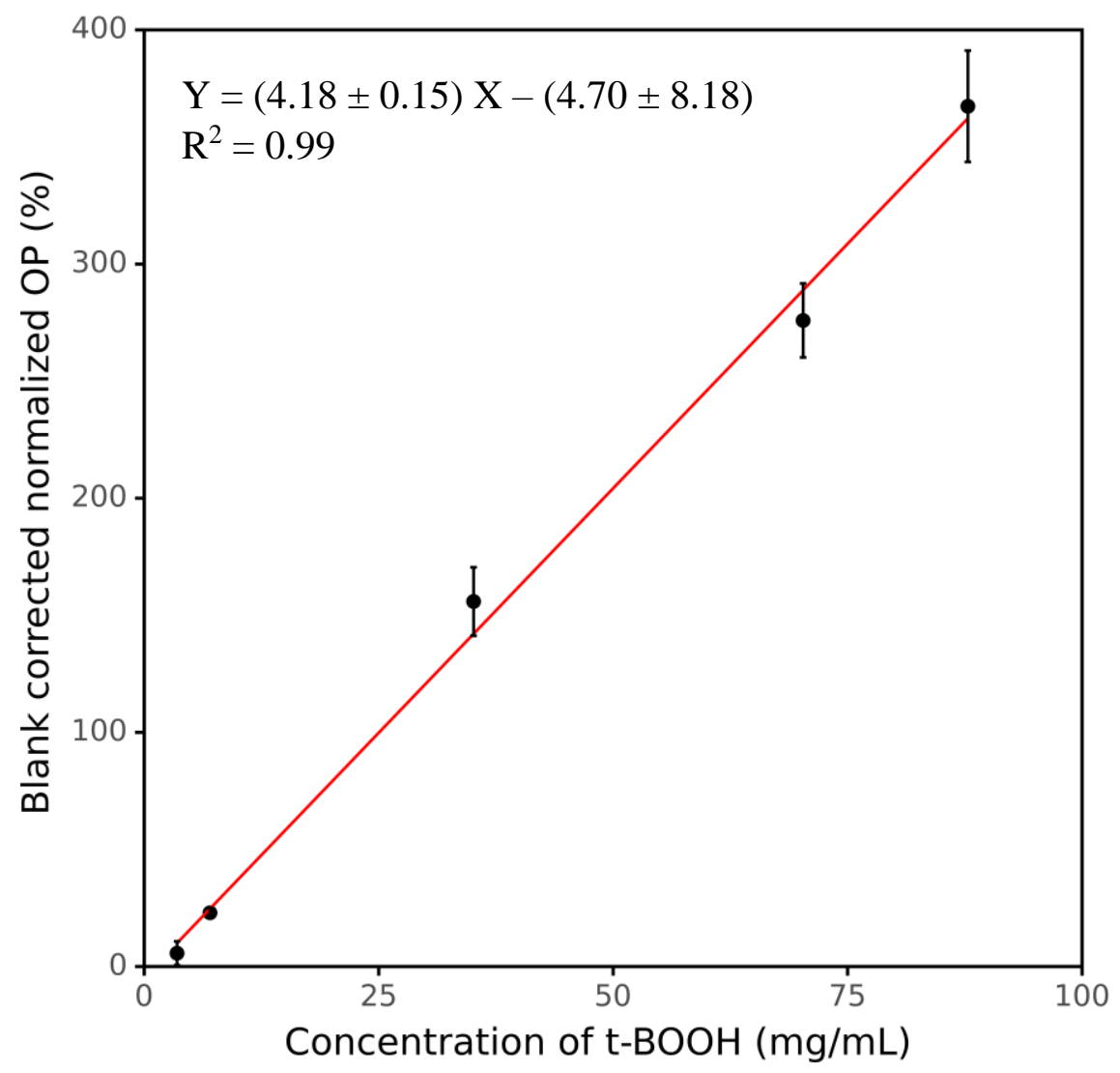

Figure 3: OP as a function of the concentration of t-BOOH, measured by our automated instrument. The values on Y- axis were obtained by dividing absolute fluorescence of the sample by absolute fluorescence of negative control and then blank correcting it (i.e., subtracting 1 from ratio and then multiplying it by 100). 
https://doi.org/10.5194/amt-2021-188

Preprint. Discussion started: 22 July 2021

(c) Author(s) 2021. CC BY 4.0 License.

(c) (i) $\begin{array}{r}\text { Atmospheric } \\ \text { Measurement } \\ \text { Techniques } \\ \hline \text { Discussions }\end{array}$

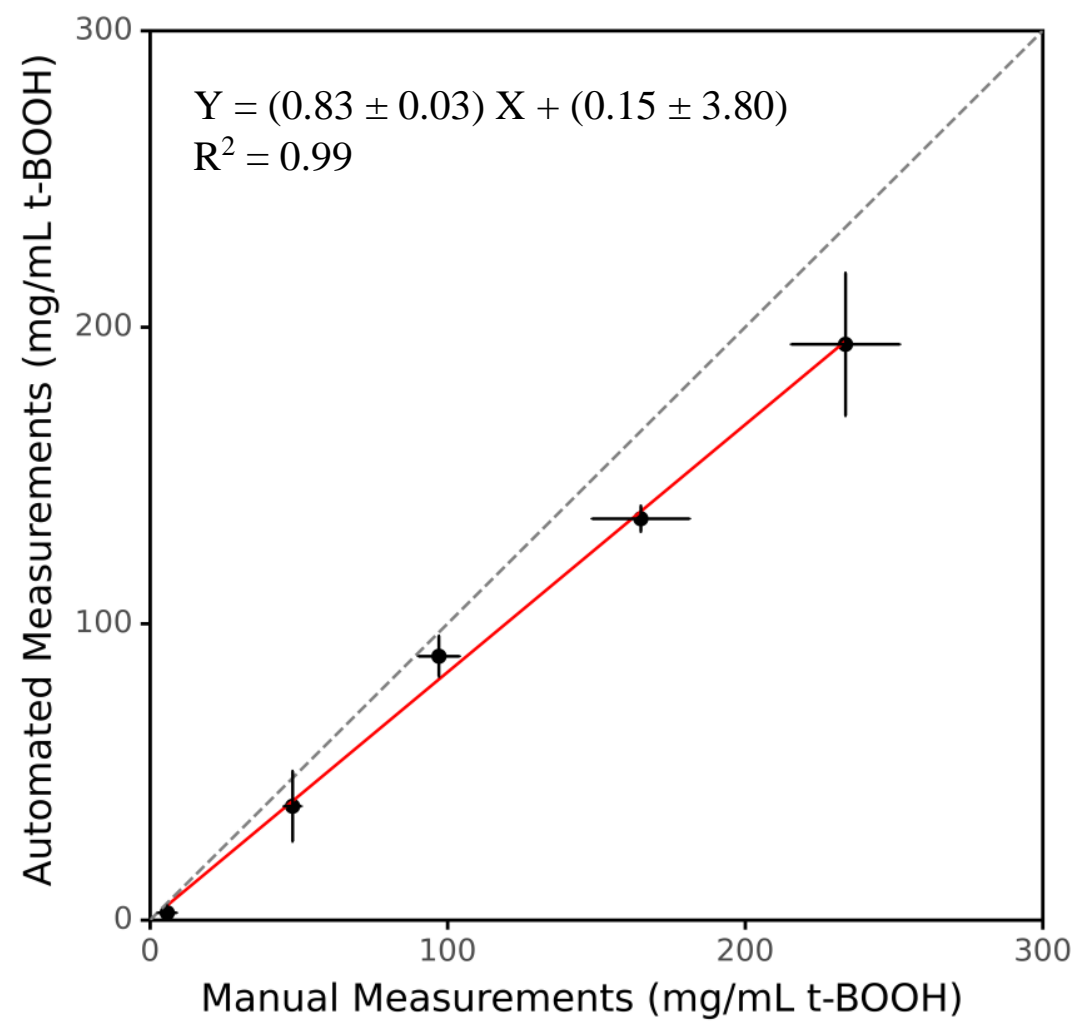

620

Figure 4: Comparison between manual and automated measurements of OP for a positive control (t-BOOH). Dotted line represents the identity line. 
https://doi.org/10.5194/amt-2021-188

Preprint. Discussion started: 22 July 2021

(c) Author(s) 2021. CC BY 4.0 License.

(c) (i)
Atmospheric Measurement

Techniques

Discussions

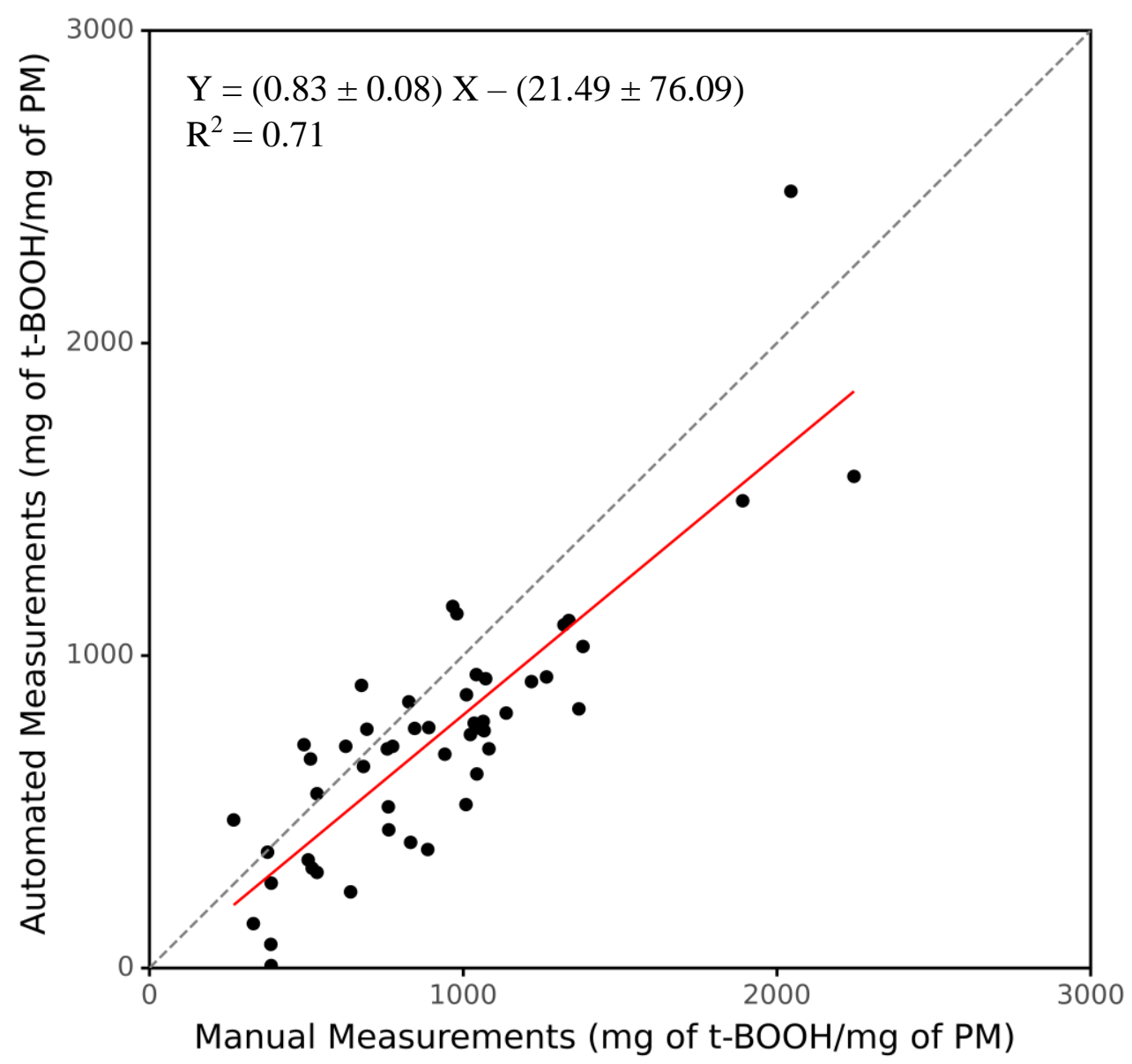

Figure 5: Comparison of the OP for manual vs. automated operation using ambient PM samples (N=50). Dotted line represents the identity line. 
https://doi.org/10.5194/amt-2021-188

Preprint. Discussion started: 22 July 2021

(c) Author(s) 2021. CC BY 4.0 License.
Atmospheric

Measurement

Techniques

Discussions
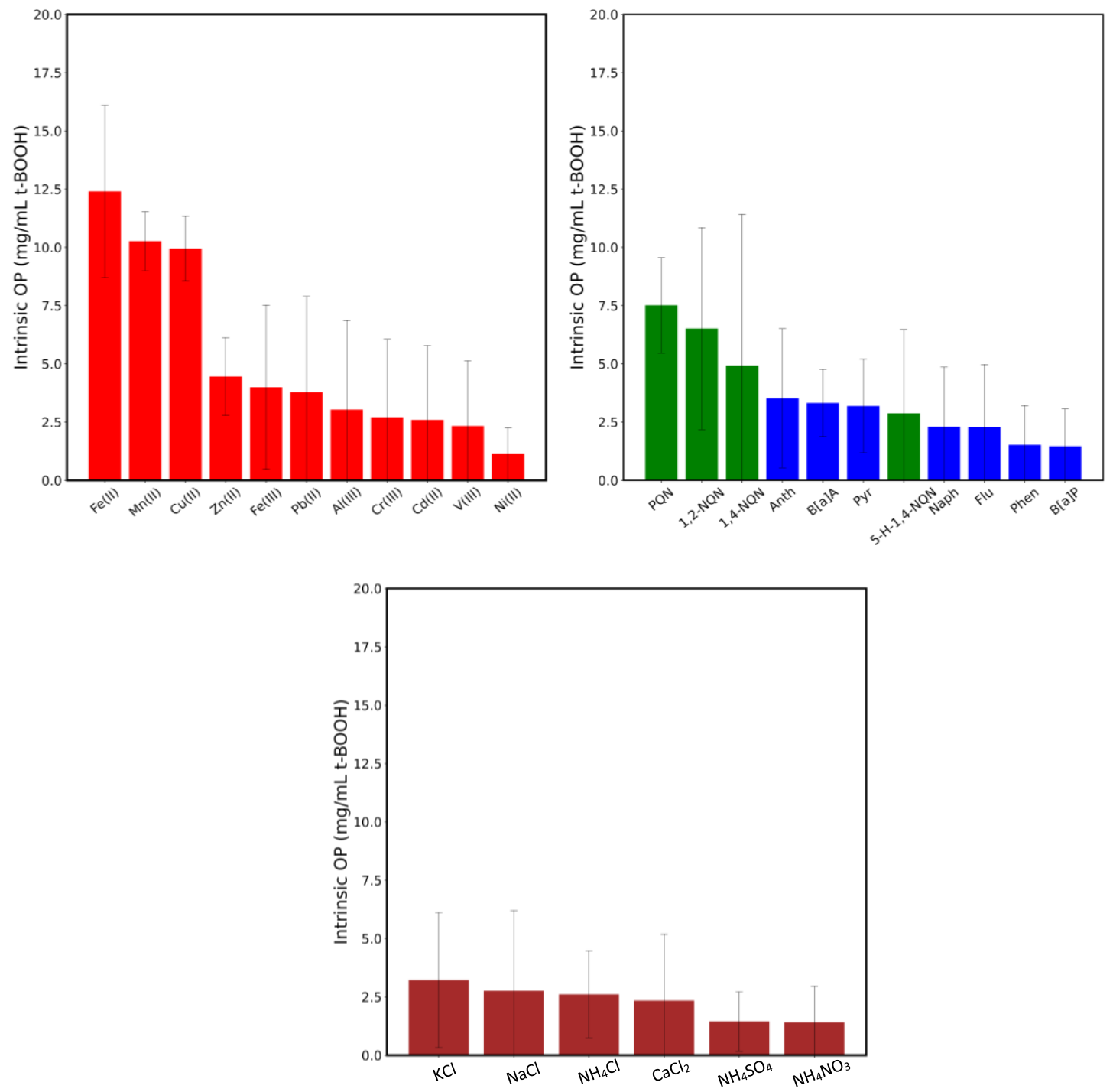

Figure 6: Intrinsic OP of 11 transition metals (panel a), 4 quinones and 7 PAHs (panel b), and 6 inorganic salts (panel c). The concentration in the $\mathrm{RV}$ was $0.5 \mu \mathrm{M}$ for all the metals; $0.2 \mu \mathrm{M}$ for all quinones and PAHs, and $5 \mu \mathrm{M}$ for inorganic salts, except for $\mathrm{NaCl}(1 \mu \mathrm{M})$. Error bars represent one standard deviation from the average. 
https://doi.org/10.5194/amt-2021-188

Preprint. Discussion started: 22 July 2021

(c) Author(s) 2021. CC BY 4.0 License.

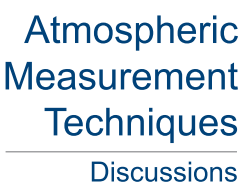

(c) (1)

Discussions

Table 1: Limit of detection and precision of the instrument obtained through the measurements of field blanks, positive control and ambient PM samples $(n=10)$

\begin{tabular}{cccccc}
\hline Sample & Unit & Average & $\begin{array}{c}\text { Standard } \\
\text { Deviation }\end{array}$ & LoD & CoV (\%) \\
\hline Field Blank & $\mathrm{mg} / \mathrm{mL}$ t-BOOH & 5.30 & 0.42 & 1.26 & 7.95 \\
t-BOOH & $\%$ ROS response & 684.71 & 111.13 & - & 16.23 \\
$\mathrm{Cu}(\mathrm{II})$ & $\mathrm{mg} / \mathrm{mL}$ t-BOOH & 71.05 & 10.18 & - & 14.33 \\
Zymosan & $\mathrm{mg} / \mathrm{mL} \mathrm{t-BOOH}$ & 18.84 & 7.15 & - & 37.97 \\
$\begin{array}{c}\text { Ambient PM } \\
\text { sample }\end{array}$ & $\mathrm{mg} \mathrm{of} \mathrm{t-BOOH/mg} \mathrm{of} \mathrm{PM}$ & 402.01 & 57.93 & - & 14.41 \\
\hline
\end{tabular}

645 